\title{
Justifying the LASPO Act: authenticity, necessity, suitability, responsibility and autonomy.
}

\author{
Felicity Kaganas* \\ Brunel Law School \\ Brunel University
}

\begin{abstract}
This article examines the ways in which the radical cuts to legal aid in private family law cases were presented and justified by the then government. It is argued that the targeting of legal aid in these cases for austerity measures was legitimated and facilitated by a skewed interpretation of history; by the use of the neoliberal discourses of responsibility and autonomy; by minimising the importance of family disputes; and by means of negative portrayals of the role of law and lawyers in such cases. The article goes on to consider the impact of the legislation and concludes that it is the competent poor, the unacknowledged vulnerable and the unassertive who are most affected by the LASPO Act. Since women, collectively, are more likely than men to fall into these categories, the result is that women, in particular, who benefited historically from wider and easier access to justice, are those who are most disadvantaged by its curtailment .
\end{abstract}

Keywords: Legal aid, family justice, private family law

\section{Introduction}

Legal Aid, from its inception, has been a major source of funding for Family Law advice and litigation. The Legal Aid and Advice Act 1949 was passed in response to a perceived need to make divorce more accessible in the light of significant demand. It was hailed as an important social welfare measure and gained cross-party support in the post-war consensus that saw Labour win on a platform that undertook to address the 'five giant evils' identified in the Beveridge Report (1942): 'Want, Disease, Ignorance, Squalor and Idleness'. In contrast, more recent years have seen the discourse of welfare superseded by talk of fiscal austerity and the need to curb out-of -control spending. The portrayal of spending on legal aid as profligate, unnecessary and something to be cut back was facilitated and justified by a number of discourses. Arguably, it was these discourses as well as negative portrayals of the legal system and of legal professionals, combined with the poor relation status of access to justice compared with pillars of the welfare state such as healthcare, that allowed the government to take access to justice out of welfare discourse entirely and to implement, relatively unopposed, the drastic cuts in family law legal aid that were enshrined in the LASPO.

*Email: felicity.kaganas@ brunel.ac.uk 
The Government has succeeded in making a virtue of eliminating legal aid almost completely from the field of private family law by invoking history, the neoliberal discourse of responsibility and its obverse, autonomy, as well as the now entrenched view that law and lawyers have little positive to offer when it comes to such disputes; any resort to law should be discouraged [see also Hunter in this collection].

This article will examine the ways in which the LASPO, particularly as it affects disputes about children, was presented and justified. It will point out that, despite the move to discredit the role of law and lawyers in the context of family disputes, there has been no attempt to oust them entirely from the family arena. Legal remedies remain available to those who are adjudged vulnerable and to those who can pay or who are willing to represent themselves. So, it will be suggested, it is the competent poor, the unacknowledged vulnerable and the unassertive who are most affected by the LASPO. Women, collectively, are more likely than men to fall into these categories and the result is that women, in particular, who benefited historically from wider and easier access to justice, are those who are most disadvantaged by its curtailment.

\section{Divorce, poor people and women}

In the early days of the development of divorce law, the grounds for divorce and the divorce process were closely linked. For example, the removal of divorce from the remit of the church and parliament was accompanied by the introduction of broader grounds and also led to a 'modest cheapening' of the process (Stone 1990, p. 384). The major change resulting from the Divorce Act of 1857, according to Stone (1990, p. 385), was an increase in the proportion of petitioners who were wives. 'The 'obvious, and probably correct explanation', he suggests, 'is that a number of very unhappy wives were at last free to obtain full divorces and to remarry' (1990, p. 365 and see p. 388).

However, while women clearly benefited from the changes, impecuniousness remained an obstacle to access to justice. While there was recognition, in principle if not in practice, that it was unjust to have 'one law for the rich and another for the poor' (Stone 1990, p. 389), since both legal separation and divorce were available only in London, poverty remained a bar to these remedies (1990, p. 386). The County Court Procedure Committee 1908, chaired by the president of the Probate and Admiralty Division, Sir John Gorrell-Barnes, noted that the cost of starting the process as well as attending and bringing witnesses to London was beyond the means of the poor and that this was a 'practical denial 
of justice' (Report of the Committee appointed by the Lord Chancellor to inquire into certain matters relating to County Court Procedure (cited by Cretney 2005, p. 275)). And this went beyond the poor; the less affluent middle classes could not afford to divorce either (Cretney 2005, p. 274). The Royal Commission on Divorce 1912, chaired by Lord Gorrell, stressed the need for equality and said that, 'if there is to be a law of divorce...there can be neither justice nor common sense in not opening [the] courts to the suitor, who claims the benefit of that law, and cannot otherwise enforce his claim' (Report of the Royal Commission on Divorce and Matrimonial Causes (cited by Cretney 2005, p. 276)).

Concern about the poor during this period was accompanied by growing pressure for gender equality. The Majority Report of the Royal Commission recommended, accordingly, that there be equality of access to divorce not only between rich and poor but also between men and women (Stone 1990, p. 393, Cretney, 2005, p. 210). In addition, the perceived significance and far-reaching consequences of family disputes made representation and adjudication at a sufficiently elevated level essential. The Commission observed that:

[T] he gravity of divorce and other matrimonial cases, affecting as they do the family life, and status of the parties, the interests of their children, and the interest of the State in the moral and social well-being of its citizens, makes it desirable to provide, if possible, that, even for the poorest persons, these cases should be determined by the superior courts of the country assisted by the attendance of the Bar... (Royal Commission on Divorce (cited by Cretney 2005, p.276)). ${ }^{2}$

A reformed Poor Persons' Procedure was introduced in 1914, exempting indigent litigants from court fees and providing that the solicitor assigned to the case could take no payment (Cretney 2005, p. 307, Morgan 1994, p. 40). This approach proved very expensive for solicitors and barristers. They had to appear for free and pay their own expenses (Cretney 2005, p. 310; Rushcliffe 1945, para 69). There was no provision for covering travelling costs and the cost of gathering evidence (Cretney 2005, p. 308, Rushcliffe 1945, para 69), and so the cost to them was considerable. In order to ameliorate this, it was decided by $1920^{3}$ that all undefended petitions and also cases involving poor people could be heard in assize towns instead of London (McKibbin 1998, p. 303, Cretney 2005, pp. 277-8).

The grounds for divorce also changed. By 1923 fertility was declining; the number of married women in the workforce was rising; the duration of marriages increased because of increased life expectancy; and a trend towards individualism was growing. All this contributed to a rising demand for divorce, especially by wives. The Matrimonial Causes Act 1923 assisted women by allowing them, like men, to petition for divorce on the grounds of their spouse's adultery. Many of the divorce petitions filed by wives cited cruelty $(22.4 \%$ in 
1954, up from 2.1\% in 1937) (McKibbin 1998, p. 303). So women were now able to call on the law in order to escape marriages they found unsustainable or intolerable.

It was not only social and legal change but also legal aid, according to Stone, that enabled 'an increasing number of the lower middle class whose marriages had broken up ... to obtain a divorce' $(1990$, pp. 397, 401, 413). And while the number of divorce petitions filed by men multiplied after each of the two world wars (1990, p. 401), the twentieth century was notable for the predominance of wives as petitioners. The proportion of women petitioners jumped from 39\% in 1923 to $63 \%$ in 1925 (1990, p. 396) and by the 1980s the proportion had risen to $70 \%$ (1990, p. 420). It seems reasonable to infer from this that it was mainly wives who took advantage of the poor persons' procedure and later, legal aid, to free themselves from their marriages. Legal aid was instrumental in effecting the changes that enabled Stone to conclude: 'The poor now have equal access to the divorce court with the rich, as do wives with husbands, thereby doing away at last with two ancient injustices (1990, p.421).

\section{Introducing legal aid}

It was the Second World War that eventually led to modern legal aid; solicitors were called to serve in the forces and those who were left had to bear the burden of dealing with a rising tide of divorce cases (Cretney 2005, p. 311, Morgan 1994, pp. 40-44). Legal Advice Bureaux were established to take on some of the workload and a Services Divorce Department was set up (Cretney 2005, p.311, Rushcliffe 1945, paras 23-31; 71-75). According to Morgan, this 'state provision of advice and of special arrangements within the Poor Persons Procedure for the armed forces provided inspiration for those who argued that state involvement in the provision of legal services as a whole should be extended' (1994, p.63).

In 1944 the Rushcliffe Committee was set up to enquire into and to make recommendations to enable poor persons to obtain the legal advice and representation they needed (1945, para 1). A central aim of the Rushcliffe Report was to shift the onus from the legal profession to the state. The summary observed that, 'Poor Persons place a very considerable burden on both branches of the legal profession and the government considers it is no longer fitting that this burden should be borne by one section of the community.' (Legal Aid and Advice Bill: Summary of the Proposed New Service (cited by Morgan 1994, p. 66)). The Report in turn stated: 
We think that it would be impossible to expect any extension of gratuitous professional services, particularly as there appears to be a consensus of opinion that the great increase of legislation and the growing complexity of modern life have created a situation in which increasing numbers of people must have recourse to professional assistance.

(Rushcliffe 1945, para 125)

In addition to concerns about the financial drain on the profession, there were other considerations driving the impetus to introduce state legal funding. The move towards the provision of legal aid can be regarded as a measure adopted to secure the co-operation of the nation in time of war. It has been attributed also to the insights brought about by the 'contest between the rule of law and the exercise of arbitrary and tyrannical power, which ....made everyone ready to examine the difficulties that impaired the individual's power of establishing his rights' (HC Deb, 1948, Major Sir Davd Maxwell Fyfe, col 1243 ). In addition, it has been seen as a response to the uncertainty characteristic of war and the undermining of the normal 'insurance principle for dealing with life risks' (Morgan 1994. p. 74).

The unpredictability of events and the unwanted nature of much litigation is something the Rushcliffe committee appreciated and it took the view that people could not be blamed or held responsible for becoming embroiled in legal disputes. The Report states:

An outstanding characteristic of expenditure on legal matters is that people may be involved in litigation through no fault of their own, and the costs of that litigation may be far beyond their financial circumstances. Many people of moderate means, who in the ordinary way would not contemplate seeking aid from the State may suddenly find themselves in urgent need of help for this special purpose. In our view people in this position should be able to get the help they need without being treated as "poor persons".

(Rushcliffe 1945, para 142)

Parliamentarians debating the Legal Aid and Advice Bill described the proposed legislation as a 'very essential part of our scheme for social security' (HC Deb 1948, Lieut-Col Lipton, col 1304) and as something that would 'add greatly to the general scheme of our already considerable social welfare legislation' (HC Deb 1948, Brigadier Medlicott, col 1261). So, while it was not one of the four priorities identified by Beveridge (Hynes 2012, p.21), the legal aid legislation was part of a wider move to effect social reconstruction in the post-war period, which included the creation of a National Health Service, education reform and social security (Morgan 1994, p73). It was hailed as a 'great, bold and imaginative Measure of social reform'(HC Deb 1948, Mr William Wells, col 1291). 
That setting up a new legal aid system was envisaged as an ambitious project is apparent in the goals of the early reformers. Legal representation was considered essential in cases other than in some simple county court cases; the Rushcliffe Committee made it clear that judges should not be expected to make decisions on the basis of information supplied by litigants in person and that the deficits in cases presented by unrepresented parties could not be made good by judicial assistance (Rushcliffe 1945, para 163).

The general principles set out by the Rushcliffe committee were potentially far-reaching:

1) Legal Aid should be available in all Courts and in such manner as will enable persons in need to have access to the professional help they require;

2) This provision should not be limited to those who are normally classed as poor but should include a wider income group;

3) Those who cannot afford to pay anything for legal aid should receive this free of cost. There should be a scale of contributions for those who can pay something towards costs;

4) The cost of the scheme should be borne by the State but the scheme should not be administered either as a department of State or by local authorities

(Rushcliffe 1945, para 127)

The Legal Aid and Advice Act 1949 incorporated the recommendations of the Rushcliffe Committee. According to Cretney, 'The Legal Aid Act of 1949 has the claim to being the most significant of all the various influences of the development of the family justice system in this country' (2005, p.275). In the House of Commons debates concerning the Legal Aid Bill there was no dispute as to its merits (HC Deb 1948, Mr Eric Fletcher, col 1249). It was considered desirable in that it would go some way to 'open[ing] the doors of the courts freely to all persons who may wish to avail themselves of British justice without regard to the question of their wealth or ability to pay' (HC Deb 1948, The Attorney-General, Sir Hartley Shawcross, cols 1221, 1223). If anything, the reservations expressed by some Parliamentarians raised concerns that the proposed legislation might not go far enough in assisting the middle classes.

While litigation was not seen as something to be encouraged, the problem facing the House was not constructed as unnecessary use of the courts and unjustifiable litigiousness. It was constructed as inequality in access to justice and the consequences of this inequality for the poor and those of the middle classes who were not in a position to pay. Mr Emrys Robert said: 'People must not be encouraged lightly to go to courts of law. As against that, it is equally important that persons should not feel aggrieved that they have been deprived of access to the courts' (HC Deb 1948, col 1285). That access to justice was a right, and that it 
was the state rather than the profession that should take responsibility for securing it, was stressed by Major Sir David Maxwell Fyfe (HC Deb 1948, cols 1243-4).

Mr Eric Fisher, in turn, said of the Bill:

It enshrines the principle that the citizen is entitled to legal aid as of right, and not as of charity. It will go a long way to establishing that equality before the law without which there cannot be any real social justice in this country

(HC Deb 1948, col 1249).

For many years past litigation has tended to become the privilege of either the very rich or of the very poor, or of those persons who are fortunate enough to have the backing of wealthy corporations, insurance societies, trade unions, or some other similar organisation.

(HC Deb 1948, col 1251)

He went on:

That has been bad, not only for the people who have suffered in consequence but also for the common law of England. The evolution and development of our common law and our legal institutions depend upon the fact that for generations the law has been concerned with the social and human problems that arise from the daily round of every-day life by all classes of the community. It is very desirable, if our legal institutions are to develop healthily, that legal principles should be continually applied to the changing conditions of our increasingly complex society, and that all kinds of problems should come before the courts for free ventilation and judicial interpretation. It makes our legal system unreal if it becomes remote from the problems of every-day life.

$(\operatorname{col} 1251)$

Legal aid was not to be all-encompassing; provision was not made in the legislation for representation in libel actions or in tribunals where counsel and solicitors did not normally attend. However, this was not considered a virtue of the system and it was hoped that legal aid might be extended in future. The Attorney General said:

We thought, having regard to the practical considerations - the shortage of personnel, the cost of the scheme, and so on - that the best thing at this stage was to say, "Exclude these altogether; see how the scheme works, wait until it has got into its stride, and then consider whether the exclusion of these causes of action or different types of tribunal is really resulting in any serious injustice or complaint." I say at once that I should have liked to have seen the full proposal of the Rushcliffe Committee adopted. I think it is the logical and the best thing that one can easily support on grounds of principle. But after the closest study of the matter we felt that so to do would be prejudicing the chances of the scheme in its initial stages. As it is, it will result in an enormous increase in the work of the courts and of the profession, and we felt quite clear that to go further than we have would be to overload this scheme and perhaps to endanger its success.

(HC Deb 1948, col 1234) ${ }^{4}$ 
So, cost was also an issue when the 1949 legislation was being prepared (Spencer 2002, p. 256). And, by 1951, funding of the legal aid system and the costs of proceedings in the High Court were becoming a matter for concern for the Lord Chancellor's department (Cretney 2005, p. 287). To reduce costs, divorce jurisdiction was eventually conferred on the county court by the 1963/4 administration (Cretney 2005, p. 287) and it was conferred for defended divorces in 1984 (Cretney 2005, p. 288). In the years that followed, successive governments have struggled to find ways of controlling the cost of legal aid (see Hynes (2012) pp. 27-31). The LASPO has been the most swingeing.

\section{Justifying LASPO}

\section{First principles}

Lord Shawcross in the Commons debate on the Legal Aid and Advice Bill suggested that one quarter of the population would be able to take advantage of its provisions (HC Deb 1948, col 1238). However Morgan refers to an estimate that, in 1950, when the scheme began, the proportion of the population eligible for Legal Aid on income grounds was actually over 80\% (1994, p. 67). Nevertheless, say Hynes and Robins:

\footnotetext{
At no point in legal aid's ... history has the reality of the publicly funded legal sector ever matched the aspirations laid down in the Rushcliffe Report. It has never been a universal service available to all who needed it, a legal service equivalent to the National Health Service.

(2009, p.131)
}

That legal aid was initially restricted in scope (Hynes 2012, p. 24), says Hynes, could be explained by the financial situation after the war. However, constraints continued into the 1960s boom times and this, he suggests, is because legal aid did not enjoy the same priority as Beveridge's four pillars. Legal Aid did increase in scope with the expansion of the welfare state from the mid-70s (Hynes 2012. pp. 25-6) but from the mid-1980s the cost of legal aid came to be seen as a problem and civil legal aid came to be largely a 'sink service for people on means tested benefits' (Hynes 2012, p. 28).

That the Legal Aid system never rose to the expectations of its early proponents is perhaps cause for regret. Certainly, as the Attorney General said in 1948, there was some regret that Rushcliffe could not be implemented in full (see above). The general view of Parliamentarians debating the Bill was that access to the courts should be regarded as a right, not something contingent on the charity of the legal profession. Yet the supporters of the 
LASPO Act present the new limits placed on the legal aid system as if they were a crucial part of the original master plan. The new restrictions are justified as being in keeping with the founding principles of the legal aid scheme.

The Consultation document preceding the changes introduced by the LASPO Act presents the legal aid system as having expanded beyond recognition and as spiralling out of financial control:

The current scheme bears very little resemblance to the one that was introduced in 1949. It has expanded, so much so that it is now one of the most expensive in the world, available for a very wide range of issues, including some which should not require any legal expertise to resolve. I believe that this has encouraged people to bring their problems before the courts too readily, even sometimes when the courts are not well placed to provide the best solutions. This has led to the availability of taxpayer funding for unnecessary litigation. There is a compelling case for going back to first principles in reforming legal aid.

(MOJ 2010, p. 3, Executive Summary, para 4.3)

However, while the changes are presented as a return to first principles and as restoring legal aid to what it was always intended to be, the first principles referred to are not those of welfare, social insurance or state guarantees of rights, justice or equality. They appear to relate principally to the narrower scope of the 1949 Act and to the view, occasionally mentioned in the debates on the original Bill, that litigation should not be encouraged.

\section{Unnecessary litigation}

Rather than reflecting the first principles underlying the founding of the legal aid system, the assertion that legal aid should be restricted because it encourages unnecessary litigation echoes the views expressed in the earlier second Finlay Report on legal aid for the poor. This report concluded that there was no need for a civil legal aid system:

[T]here are many cases where, though there may be some violation of a legal right it is neither prudent nor advisable to litigate. We believe any scheme which might tend to make people more litigious should be deprecated.

(Committee on Legal Aid for the Poor 1928 (cited by Morgan,1994, p. 50)).

The Report rejected a suggestion that 'legal hospitals' be established. It took the view that legal aid was not comparable to medical aid because 'it is manifestly in the interests of the State that its citizens should be healthy, not that they should be litigious' (Goodhart 1945, xi). Goodhart's criticism of this negative construction of litigation remains pertinent. He asks whether: 
a poor man who asks for justice in the courts is properly described as "litigious"? Is it not more correct to say that it is a paramount interest of the State that its citizens, whether rich or poor, should not be deprived of that justice which Aristotle described as being an essential element of the "good life"?

(1945, xi-xii).

Yet the modern day debate on family law legal aid continues to cast those who resort to law as unnecessarily litigious.

In addition to that objection, the current exclusion of private family law cases from the ambit of legal aid is justified on apparently practical grounds; the nature of family law cases makes legal involvement unnecessary. The 2010 Consultation Paper, for example, suggests that legal aid had been funding cases which needed no legal expertise (MOJ 2010, p. 3, Executive Summary, para 4.3). This reasoning too echoes the Finlay Report which suggested that, 'a large proportion of the cases in the County Court are simple in character and the judge is well able to ascertain the facts ... so that it is not necessary or advantageous that there should be any legal assistance at all' (1928, para 12 (cited by Morgan 1994, p.51)). ${ }^{5}$ Rushcliffe, in contrast, was clear that courts could not be expected to decide cases on the basis of information provided by LiPs and the Royal Commission (1912, above) thought representation crucial given the grave consequences of family disputes.

In the early days after the 1949 Act, the most significant proportion of civil legal aid was spent on family matters ${ }^{6}$ and the use of legal aid for this purpose was considered justified by the early reformers on the basis of the complexity and importance of cases as well as on moral grounds. Although the state today is less concerned, if at all, with the moral implications of divorce, and the simplified procedure makes legal advice unnecessary for filing divorce petitions, there are still questions of enormous importance relating to the end of marriage and, indeed cohabitation: finance and children. Private family disputes are often complicated and legal expertise is needed in order to resolve them. Yet mediation and other forms of ADR are considered more appropriate.

\section{A preference for mediation}

It is now received wisdom that law and lawyers should be avoided in private law family disputes. The Executive Summary of the Family Justice Review refers to prevailing perceptions of lawyers as 'generally [taking] an adversarial approach that inflames rather than reduces conflict' (Norgrove, 2011b, para 105). And, as Diduck and Kaganas observe, there has been a 'remarkable degree of consensus about the limitations of law and the courts in dealing with family disputes, particularly disputes about children' $(2012$, p. 707) [See also 
Hunter in this collection]. There has been a long-standing trend favouring the 'dejurification' of family law and promoting alternative means of dispute resolution such as mediation (Trinder 2015, p. 224). Indeed litigation came to be seen as a last resort and ADR had already come to be seen as a better way of dealing with family disputes in the 1970s following from the recommendations of the Finer Committee (DHSS 1974). ${ }^{7}$ This drive to promote mediation has intensified since.

Documents published by successive governments, ${ }^{8}$ and in particular the 2010 Consultation paper, ${ }^{9}$ have warned of the pitfalls of resorting to law and lawyers. The Consultation Paper expresses a clear preference for 'more effective and suitable' (MOJ 2010, p. 3., Executive Summary para 1.8) alternative dispute resolution processes. In the Foreword to the Consultation paper, the Lord Chancellor wrote:

I want to discourage people from resorting to lawyers whenever they face a problem, and instead encourage them, wherever it is sensible to do so, to consider alternative methods of dispute resolution which may be more effective and suitable.

(MOJ 2010, p. 3)

The Interim Report of the Family Justice Review highlighted concerns about the proliferation of private law disputes, costs, delay and the inappropriateness of litigation:

104. There has been a move within the current private law system to recognise that cases can and often should be diverted away from the courts where it is safe to do so. The range of support available to allow separating families to resolve disputes outside court has developed over the years to include mediation, collaborative law and Separating Parents Information Programmes. ${ }^{10}$ These services can support parties to resolve issues themselves through discussion and negotiation that may be more sustainable and at lower cost than going to court....

(Norgrove 2011a, Executive Summary)

105. The state cannot fix fractured relationships or create a balanced, inclusive family life after separation where this was not the case before separation. Court is generally not the best place to resolve these disputes. Where possible, disputes should be resolved independently or using dispute resolution services such as mediation, when it is safe to do so. Parents who choose to use the court system must understand it will not be a panacea. Courts will only make an order where this is in the best interests of a child. Further, where the court does make an order, this may well not be in line with one or both parents' expectations or wishes. People need to expect that court should be a last resort, not a first port of call. (ibid, emphasis in original). ${ }^{11}$

A decade ago, the government was extolling the benefits of agreement for children: 
For the majority of children, their best interests will be served by maintaining a continued and constructive relationship with both parents, assuming that it is safe for them to do so. In these cases, our overall aim is to provide families with readily accessible help, advice and support, which will enable them to reach agreements between themselves, without the need to go to court. Evidence suggests that such agreements are almost always better for families, because they cause children less distress and work better over the long term than arrangements that flow from court based resolutions.

(DCA 2005, para 7.9)

So agreements reached through mediation or other forms of ADR are considered more 'sustainable', more likely to satisfy the parties, more likely to be best for children and less likely to produce or exacerbate damaging conflict. ${ }^{12}$ The Family Justice Review described one of its tasks as being to examine the alternatives to the 'adversarial' court system. ${ }^{13}$ It did, however, accept that, if efforts to reach agreement fail, there should be 'access to court processes...that resolve conflicts as fast as possible and without inflaming matters further' (Norgrove 2011b, Executive Summary, para 104). It enumerated a number of situations where it considered court intervention necessary. It referred, as 'requiring court determination', to cases 'with significant complexity, a point of law or pivotal point of fact to be considered, or where there are serious welfare concerns' (Norgrove 2011a, para 5.125). Such cases are not captured by the LASPO Act (Cobb 2013, p. 6). Not everyone who cannot agree has access to legal solutions, even if the case falls into Norgrove's categories; the allocation of legal aid is made on the basis of need.

\section{Need}

Need is deployed as a rationing device:

Our aim is not just to bring down the cost of the scheme, but to do so in ways that ensure limited public resources are targeted at those cases which justify it and those people who need it.

(MOJ 2013a, para 2.4)

1.2 The Government strongly believes that access to justice is a hallmark of a civil society. The proposals set out in this consultation paper represent a radical, wideranging and ambitious programme of reform which aims to ensure that legal aid is targeted to those who need it most, for the most serious cases in which legal advice or representation is justified.

(MOJ 2010, Executive Summary)

The criteria for deciding what should remain within the scope of legal aid were:

4.12 .....the importance of the issue, the litigant's ability to present their own case (including the venue before which the case is heard, the likely vulnerability of the 
litigant and the complexity of the law), the availability of alternative sources of funding and the availability of alternative routes to resolving the issue.

(MOJ 2010)

Having applied these criteria to family cases the then government concluded that family cases, except those where domestic violence can be established, are not as important as other pressing demands on the budget, that out-of-court resolution of disputes is best for children (MOJ 2010, paras 4.209-10), that mediation is available for resolving cases out of court, and that parents are not vulnerable in comparison with other groups (MOJ 2010, para 4.214) The Government's view was that, 'people should take responsibility for resolving such issues themselves, and that this is best for both the parents and the children involved' (MOJ 2010, para 4.210). They should use mediation and keep court proceedings to the 'minimum necessary' (2010, para 4.69). It is clear, then, that family disputes were, and are, no longer constructed as legal problems warranting legal solutions. ${ }^{14}$

In the eyes of the successive recent governments, legal aid is 'necessary' only in cases of narrowly defined need. Those who need access to lawyers and courts and for whom such access is therefore justified are those designated as vulnerable. The terms of reference of the Family Justice Review (Norgrove 2011a, Annex A) stated that the courts' role should be to protect the 'vulnerable' from 'abuse, victimisation and exploitation'; 'courts should avoid intervening in family life except where there is a clear benefit to children and vulnerable adults in doing so'. Why in effect, it is only victims of domestic violence ${ }^{15}$ and children ${ }^{16}$ who are classified as vulnerable for the purposes of the LASPO Act is nowhere explained. Nor is it explained why it is only the 'vulnerable' who need the help of the law.

The obvious answer might be that they are not seen as responsible for their problems and are not in a position to exercise the requisite autonomy to deal with them. They cannot articulate their case adequately and they are in a position of relative powerlessness; they need a representative to speak for them and to navigate the legal system. They need an impartial decision-maker rather than help with reaching an agreement. Vulnerability, says Diduck, may be the friendly face of dependency; 'vulnerability implies disability, lack of capacity, incompetence and victimhood' rather than blameworthiness (2014, p. 97). The vulnerable, unlike those deemed competent, need the 'assistance or intervention of the state' (2014, p.97).

There are other disputants, such as mothers who are placed under pressure by dominant fathers, who cannot articulate their case or bargain effectively either. Yet, perhaps because they cannot be allocated to an easily identifiable category, or perhaps because their 
plight is not so extreme, they must fend for themselves. For them, as for others more capable, a resort to adjudication is considered not only unnecessary but also an abdication of personal individual responsibility.

\section{Individual responsibility and autonomy}

The Legal Aid Consultation Paper (MOJ 2010) expresses an expectation that family disputants take responsibility both for the choices that have led to their difficulties and for resolving those difficulties without the help of the justice system.

$4.19[T]$ here is a range of ... cases which can very often result from a litigant's own decisions in their personal life.... Where the issue is one which arises from the litigant's own personal choices, we are less likely to consider that these cases concern issues of the highest importance

2.11 To help establish the right balance, we have been guided in particular by the following considerations:

the desire to stop the encroachment of unnecessary litigation into society by encouraging people to take greater personal responsibility for their problems, and to take advantage of alternative sources of help, advice or routes to resolution. ${ }^{17}$

Eekelaar and Maclean (2013, p. 10) point out that the principle that personal decisions put cases outside the scope of public concern was intended to establish that private family disputes are less serious than other types of disputes. It might also be suggested that to deny access to legal representation on the grounds of personal choices made by the parties is to discount the importance of the existence of rights and, in particular, the right to be heard; having made her/his bed, the disputant must lie in it. To make an exception only on the basis of need compounds this marginalisation of rights or legal entitlements. This is not to say that legal aid was ever or should be available to everyone. The point is that the state considers most family problems a matter of personal responsibility. ${ }^{18}$ Family disputes, it seems, are once again being relegated to the private sphere where, as has been the case in the past, there is the potential for inequality and power imbalances to be left unchecked (Diduck and Kaganas 2012, pp. 14-19, 547, 557-8). ${ }^{19}$

The emphasis on the public/private divide and the location of family disputes within the realm of the private, together with the stress on individual responsibility owes much to neo-liberal ideology and it is this ideology that is thought by many commentators to underlie the legal aid cuts [see also Rosemary Hunter and Jessica Mant in this collection].

McGregor explains that a welfare approach is characterised by a reduction of inequality and the pooling of risk whereas neo-liberalism is characterised by rising 
inequality and individualised responsibility $(1999$, p. 91). Essential to the welfare state is the 'principle of social insurance' (1999, p. 93). The move from a social insurance welfare state to neo-liberalism involves a move from government to market and from community to individual (1999, p.102). There is increased stress on fiscal austerity and balancing the budget: 'Such fiscal austerity requires constraints on public spending and thus has direct impact on the shape and size of welfare states' (1999, p.103).

However there are also features in the discourse surrounding legal aid reform of what McGregor terms the 'new paternalist social service state' (1999, p.107). This too emphasises responsibility; there are no rights without duties. Rather than risks being shared, the focus is on the individual. The aim is to get 'those receiving public services to change their behaviour and act more responsibly. It is assumed that irresponsibility is the cause of their problems' (1999, p.108). Responsible behaviour 'involves increased self-regulation'. The problem with this is, McGregor points out, that it assumes 'that it is possible always to master external forces' (1999, p.109).

This criticism is germane to litigation; respondents cannot avoid court battles which are foisted on them by claimants, for example. They cannot enter mediation if the other party refuses. And in such cases many have to enter the arena as LiPs because they cannot afford legal representation. And now, it seems, there are no litigants in private family law disputes who can be termed 'responsible' or can be described as acting 'responsibly'; only those who are vulnerable should be in court. Those who are not vulnerable should avoid the legal system or they must at least take financial responsibility for their forays into law and pay for their own lawyers.

The emphasis on private resolution of disputes and on individual responsibility, as well as the marginalisation of the legal system, are all apparent in the Family Justice Review. The 'guiding principles' laid out in the terms of reference state that individuals should have 'information and support to enable them to take responsibility for the consequences of their relationship breakdown'. Mediation 'and similar support' should be used 'as far as possible' to enable parties to reach agreement 'rather than having an arrangement imposed by the courts' (2011a, Annex A). This reference to 'imposed' arrangements hints at what Diduck calls the 'friendly face' of the principle of responsibility: autonomy (2014, p. 96). The state's role is confined to helping parties to reach agreement (Herring 2010, p. 259) and, as competent adults, they are free to shape their own futures. Autonomy, says Diduck, is politically more attractive than the concept of responsibility. Rather than demanding accountability, the offer of autonomy implies choice and respect 
(Diduck 2014, p. 96). It is, therefore, clearly something to be desired and it is only the vulnerable who cannot be expected to take advantage of it. 'Family law,' says Diduck, 'seems to be reserved for the vulnerable' (2014, p. 102).

Eekelaar, in turn, suggests that 'it seems that the very presence of law, and the idea of legal entitlements in the context of family breakdown is being questioned by some policymakers' (2011, p. 317). Similarly, Atkin argues that, central to the legal aid changes, is the principle that the state should not interfere in private family life. Even if finance improves, he says, the ideology of privacy will prevail (2015, p. 39). Sommerlad too does not believe that when the economic situation gets better, the changes will be reversed: 'On the contrary, the disintegration of the private law justice system should be viewed as the ultimate goal'. The aim is to demonstrate the system is too expensive to save and that 'the state and justice system has no business in intervening in people's lives' (2015, p.264).

\section{Cost}

Whether or not there is an ideological drive to destroy the private law family justice system, fiscal considerations certainly played a large part in the campaign for change. ${ }^{20}$ The Ministerial Foreword to the 2010 Consultation Paper stated:

Legal aid must also play its part in fulfilling the Government's commitment to reducing the fiscal deficit and returning this country's economy to stability and growth. The proposals on which I am consulting are therefore designed with the additional aim of achieving substantial savings.

(MOJ 2010, p. 3)

The Minister, when questioned by the House of Commons Justice Committee, explained that 'the economic situation that the Government inherited' did not allow time to conduct research on the desirability of the changes before making them (House of Commons Justice Committee 2015, para 9). Dame Ursula Brennan, the Permanent Secretary at the Ministry of Justice, when questioned by the Public Accounts Committee, identified the primary motivation for the changes as financial: "I was simply saying in terms of the evidence, the most critical piece of evidence that was relevant to the decision that was made was the size of the spend" (House of Commons Justice Committee 2015, para 8). ${ }^{21}$

Judicial assessments of the purpose of the legislation emphasise financial considerations while noting the exceptions for deserving cases:

41 Drawing the threads together it seems to me that the purpose of the statute (or, more crucially, the relevant parts of the statute) read as a whole is partly to withdraw 
civil legal services from certain categories of case in order to save money but also to make such services available perhaps not to the entire membership of most deserving categories of case (such as victims of domestic violence) but at any rate to the great majority of persons in the most deserving categories.

$\left(R\right.$ (Rights of Women) $v$ Secretary of State for Justice [2016] EWCA Civ 91). ${ }^{22}$

The government at the time, like its predecessors, was committed to mediation and ADR to resolve family disputes. To promote these, however, it might have contented itself with something akin to the previous Labour government's policies of providing early support and alternatives to litigation. It was not essential to, in effect, cut off access to courts through restricting legal aid. That the Coalition government chose the latter course might be evidence of a more radical ideological stance than Labour's. Alternatively, the fact that there are exceptions to the cuts might suggest that the drastic curtailment of legal aid was also, to a significant degree, a response to fiscal pressures. The exceptions point to an acknowledgment that some cases must remain in the public sphere.

It seems, then, that it was not only that the state embraced the ideology of privacy and non-intervention, it was the protection of the public purse that was also important. However, it is ideology that points to which services can be considered most appropriate for the purpose of making fiscal savings. ${ }^{23}$ It is clear from the pronouncements and explanations leading up to the enactment of the LASPO Act that the family justice system was identified as a suitable target. And what made it appear a relatively easy target were the arguments and discourses undermining its utility, effectiveness and suitability.

\section{LASPO - the effects}

It is mainly the less well-off who are feeling the effects; it is they who must conform to the norms of autonomy and individual responsibility. It is they who must take responsibility for their bad choices. Whatever the perceived benefits of mediation and whatever the perceived wastefulness and irresponsibility of litigation, courts are not off-limits ${ }^{24}$ to those who can afford to pay lawyers to help them unravel the tangles caused by poor life choices. ${ }^{25}$ Nor are they off-limits to those who can represent themselves.

The effects of the legislation were evaluated by the National Audit Office. These were found to be a reduction in civil legal aid spending but a potentially significant rise in costs generated by the increase in the numbers of LiPS and also in the possible adverse effects, including health problems, resulting from the failure to resolve problems that would otherwise have fallen within the remit of legal aid. There was a fall in the numbers of 
mediation cases and there was no way of knowing whether those eligible for legal aid were accessing it, particularly in the light of the depletion in numbers of legal aid practitioners. The government, said the NAO, had no understanding of how the changes would influence individual behaviour or the market in legal services when it implemented the changes (NAO 2014).

A Parliamentary Committee has also reported on the legislation. ${ }^{26}$ It noted the government's objectives of discouraging unnecessary litigation; targeting legal aid at those who need it most; making significant savings; and delivering better value for money for the taxpayer. ${ }^{27}$ It concluded that, "while it had made significant savings in the cost of the scheme, the Ministry had harmed access to justice for some litigants and had not achieved the other three out of four of its stated objectives for the reforms' (House of Commons Justice Committee, Summary 2015, p. 3). It too noted an increase in the number of LiPs, a reduction in the number of cases going to mediation, ${ }^{28}$ and the creation of advice deserts. 'It was clear to us that the urgency attached by the Government to the programme of savings militated against having a research-based and well-structured programme of change to the provision of civil legal aid' (2015, p. 4).

The result is that solutions to problems are only now being sought. The Labour government had thought that investment in 'improved advice and support to enable the majority of families to agree contact arrangements between themselves', could 'free up greater amounts of legal aid resources to focus on those cases in which children are at greater risk of harm' (DCA 2005, para 7.10). Now, instead, legal aid has been removed, and the focus has moved to what can take its place. There will have to be reliance on law student clinics and pro bono representation (Treloar 2015, p. 36) ${ }^{29}$ the burden will shift back onto charitable bodies and the legal profession, a situation deplored by the Rushcliffe Committee. There will also be reliance on McKenzie friends, currently unregulated. ${ }^{30}$ Finally there will need to be some investment in devising ways to deal with LiPs.

The rise in the number of LiPS has given cause for concern because, although in the past the courts had seen many self-representing parties, it appears that there is a new type of LiP as a result of the LASPO. ${ }^{31}$ Giving evidence before the Parliamentary Committee, Sir James Munby said:

Previously we had a lot of litigants in person who were there through choice. They tended to be people who had a particular point of view, but who understood the case, were articulate and had the confidence to appear in court. We now have a lot of litigants in person who are there not through choice and who lack all those characteristics...

(House of Commons Justice Committee 2015, para 97) 
Women, arguably, are more likely than men to fall into this category: The Final Equality Impact Assessment confirms this:

2.131 The Family Private category represents the largest number of potential users of legal aid who will be affected by these reforms. Clients in this category are more likely to be female than in any other category of law except education, representing $63 \%$ of total clients (excluding unknowns).

3.12 Changes to the eligibility rules for civil legal aid therefore have the potential to have a disproportionate effect on women, BAME people and ill or disabled people. (MOJ, undated)

Since women are likely to be primary caretakers of their children, they tend to earn less. ${ }^{33}$ As Treloar says, men are generally in a better economic position to retain a lawyer; gender differences in access to finance can have the effect of creating gender differences in access to justice $(2015$, pp. 30, 37). In addition, it is more likely to be women who are unwilling litigants in disputes over child arrangements for contact, for example; these proceedings are generally initiated by fathers (Coy, Perks, Scott and Tweedale 2012, p. 33, Hunt and Macleod 2008, p. 239) and it is generally mothers who are seeking to resist contact (Trinder et al. 2014, p.12). And some women are harassed by repeated applications to court (Trinder et al. 2014, p. 32). Even mothers willing to mediate may not be in a position to 'selfmanage' in accordance with government aims and policies. ${ }^{34}$ They may be faced with fathers' refusal to participate and, as a result, will find themselves defending cases as LiPs.

Cobb observes that, 'Representation assures equality of arms as between privately funded and legally aided parties' $(2013$, p. 9) and there are concerns that unrepresented mothers might be forced to agree to unsafe child arrangements. ${ }^{35}$ Hunt and Macleod (2008, p. 239), for example, found that although many women opposing contact did so because of serious child welfare issues, mothers appeared to have been pressured to agree to contact. ${ }^{36}$ Indeed, there is a body of research evidence attesting to the fact that the professionals and also courts press parties to agree, and to agree to contact (Hunt and Macleod 2008, pp. 168ff, Coy et al 2012, p. 39; Kaganas 2010; Kaganas 2011). Barnett (2015 and in this collection) points out that, even before the LASPO Act, most cases were being settled and that the pressure on women to agree to child contact, sometimes unsafe contact, was often coming from their lawyers. Lawyers were criticised as being part of the problem rather than as providing protection for domestic violence victims. She suggests that lawyers have been 
repositioned now as the protectors of victims by critics of the LASPO because the focus of courts and professionals is on procedural difficulties rather than on outcomes .

However, if a case does get to court, and it seems that LiPS are less likely than represented parties to settle, ${ }^{37}$ Coy et al. (2012) suggest that outcomes could be affected. For example, LiPS who have suffered domestic violence or abuse may not be able to present evidence or to cross-examine effectively and they often do not have the legal knowledge to negotiate the legal process. For instance, they will not be aware of the possibility of asking for findings of fact hearings. ${ }^{38}$ While much depended on whether their solicitors believed them, understood abuse and were willing to present evidence of it, women participating in the study by Coy et al. 'described the ability to access free or low-cost legal advice and representation through the legal aid scheme as "a lifeline"" (2012, p. 40). ${ }^{39}$

Trinder et al. found almost all the LiPs in their study to be either struggling with legal procedures or to fall into the category of those who are 'vanquished'. 'Towards the vanquished end of the spectrum', they observe, 'were those LiPs who clearly did not understand what was happening at court, were out of their depth, and had limited capacity to participate in any effective way'. They included LiPS 'who simply cried in court ... or who were so paralysed by fear, overwhelmed or intimidated that they were incapable of advocating for themselves and their children' (2014, p. 26). Their difficulties were often compounded by vulnerabilities such as 'being a victim of violence or abuse; mental health, drug or alcohol problems; learning impairments, other physical or behavioural disabilities; illiteracy and language difficulties' (2014, p. 28). The researchers also report that they observed LiPs who 'appeared to have been pressured into an agreement where a competent lawyer would have been able to make a powerful case based on the worrying evidence that the researchers found in the court file' $(2014$, p. 76). So it seems that women who are LiPs or whose former partners are LiPs can be disadvantaged in many ways.

Cases where there is no legal representation appear to be more likely to collapse (Trinder at al. 2014, p. 59) and of course, there are and will continue to be cases where parties, including fathers seeking contact, simply give up or, as Hunter says,' lump it' (2014, p. 662). However it is likely to be the more quiescent mothers and those fathers who are less dominant and aggressive who will give up. In contrast, it is those fathers who do pose a threat, or at least a problem for mothers and children, who will persist in litigating. In any event, even if parties do retire from the court arena, this does not mean the problems will go away (Hunter 2014, p. 662). Parties may find that the conflict persists to the detriment of the children involved. ${ }^{40}$ 
Despite criticism of the legislation, the government remained unmoved:

19. The Government considers that the impact of the policies on children will be mitigated by targeting legal aid on the highest risk cases - those involving domestic violence and child abuse... as well as continuing to fund international child abduction cases... and child parties in private family law cases.

$(\text { MOJ 2011b) })^{41}$

And, as far as women are concerned, the final Equality Impact Assessment had nothing to say. It stated that 'taking ... matters into consideration, as well as the need to prioritise finite resource on those most in need, we believe these reforms are a proportionate means of achieving our legitimate aims.' (MOJ undated, para 2.135). Moreover, while some private family law cases might be complex, the exceptional cases provision would be adequate to deal with these (para 2.138). ${ }^{42}$ In any event, mediation and assistance for LiPs were sufficient and the government planned to review what was available (para 2.139). ${ }^{43}$ In short, private family law was (and is) simply not as important as other demands on resources: 'The Government needs to prioritise its resources, and does not consider most private family law cases as high priority for legal aid compared with cases, for example, involving homelessness, domestic violence or liberty' (para 2.138).

Of course, since that document was published, more evidence on the operation of the LASPO Act has emerged to contradict the Coalition Government's predictions. The exceptional cases funding provision has been narrowly interpreted and few applications are being granted (House of Commons Justice Committee, 2015, paras 30ff, MOJ and Legal Aid Agency 2015, p. 33). The domestic violence gateways are still restrictive; the difficulties in acquiring the necessary types of evidence prevent victims qualifying for legal aid (House of Commons Justice Committee 2015, paras 63ff); ${ }^{44}$ and vulnerable parties unable to afford legal representation find themselves being cross-examined by their abusers (House of Commons Justice Committee 2015, para 107, Coy et al. 2012, p. 38). The regulation dealing with domestic violence has been declared invalid insofar as it specified a 24 month deadline and failed to take account of financial abuse. ${ }^{45}$ These problems were addressed but the gateways are again under review (Bowcott 2017). Family lawyers are going out of business and the take up of mediation has been modest (MOJ and Legal Aid Agency 2015, p. 23, Trinder et al. 2014, p. 2, Hunter in this collection). The number of reported cases has dwindled to a handful, ${ }^{46}$ presumably because cases do not go on appeal. There is no longer scrutiny of decisions as a result. The courts are no longer exposed, to the same extent, to 
outside evaluation and criticism of their decisions. ${ }^{47}$ The development and interpretation of the law, in turn, may be stultified. Indeed, the Lord Chief Justice has commented ${ }^{48}$ that without a 'steady diet of cases', the common law will cease to develop and will ossify (Rozenberg 2016).

\section{Conclusion}

A combination of factors has worked to make the legal aid cuts appear justifiable and even desirable. There is the appeal to an earlier 'authentic' legal aid system. By relying on an historically selective account of the genesis of legal aid, the government has been able to present the restrictions as a return to the 'principles on which [the system] was founded' (MOJ undated, para 62). Compared with its original incarnation, legal aid had, it is suggested, grown into a bloated monster, consuming taxpayers' money in order to indulge the whims of unworthy combatants. This depiction supports the Government's argument that it is essential to balance the books and that cuts to legal aid are a reasonable and relatively painless way of doing so. Recourse to law and especially to the courts is constructed as a problem where private family law is concerned: it is wasteful, unnecessary, morally questionable as an abdication of responsibility and also financially indefensible. Private family law disputes are presented as less complex and less important than other legal issues and both the law and lawyers, represented as ineffective and conflict generating, are easily dispensed with in favour of mediation. Neo-liberal ideology as well as the newer "paternalist social service state' demand that individuals take responsibility for their choices and for resolving disputes without requiring courts to do so for them. And if they insist on going to court they should be self-funding or self-representing; taking responsibility means one should not expect the state or the taxpayer to pay. Moreover, ADR is presented as offering opportunities to engage in autonomous decision-making. All this, it seems, leads to the conclusion that cuts to legal aid for private family law do not adversely affect society and citizens. In any event, measures are in place for hard cases to help LiPs and to protect the vulnerable.

The idealism of Rushcliffe and of the members of Parliament who enacted the 1949 legislation has vanished and some of the consequences predicted at that time if legal aid were not available have materialised. For example, we do not really know, now, how the law is being applied and interpreted in disputes about children as s8 Children Act cases are now rarely reported. We do not even know how the new presumption in $\mathrm{s} 1(2 \mathrm{~A})$ favouring the involvement of both parents in their children's lives is operating in all but a few cases. The 
consequence is likely to be that the development of the law will be stunted, or, at any rate, hidden from the public gaze.

The LASPO Act is not a return to the principles that animated the 1949 legislation; it has been a significant departure. It has embodied a shift from the notion of social insurance and an acknowledgment of the unpredictability of people's lives to a privatisation of family disputes and a demand that people accept responsibility for events. The aim of the LASPO Act was not to extend access to justice but to solve the problem of too much access. The aim is no longer to shift the burden of helping those with legal problems from charities and the profession to the state. Rather all talk now is of shifting it back. The aim is no longer to achieve equality between rich and poor and between women and men; the availability of mediation, the unimportance of family disputes and the financial imperatives driving the state render the legislation 'proportionate'. The disproportionate impact of the legislation on women and some children is perhaps the most striking reversal.

The introduction of legal aid in the last century enabled women to escape from unhappy and sometimes abusive marriages. The withdrawal of legal aid now has the potential to leave many women 'vanquished' or in continuing dispute over child arrangements; many will be trapped in conflict, and sometimes dangerous conflict, with little hope of resolution.

\section{Notes}

\footnotetext{
${ }^{1}$ The relative poverty of women is apparent in the results of the passing of The Matrimonial Causes Act 1878 and Married Women (Maintenance in Cases of Desertion)1886, followed by the Summary Jurisdiction (Married Women) Act 1895 which enabled a deserted or battered wife to obtain a separation and maintenance order from a magistrate (Cretney 2005, p. 200). These led to an 'avalanche of applications to the magistrates' courts' (Stone 1990, p. 386).

${ }^{2}$ See also Morgan (1994, pp. 52-54).

${ }^{3}$ See The Administration of Justice act 1920.

${ }^{4}$ The problem of the unforeseeable extent of the cost involved was remarked upon in relation to the poor persons' procedure some years earlier: 'The serious impediment will probably turn out to be the reluctance of the Treasury to consent to expenditure the limits of which cannot be foreseen!' (The Times, 30 December 1914 (cited by Morgan 1994, p. 42)).

${ }^{5}$ Trinder et al. (2014, p. 29) point out that family cases are not simple.

${ }^{6}$ See Hynes (2012, p. 24).

${ }^{7}$ See further, Kaganas (2010, p. 237).

${ }^{8}$ See, for example, Eekelaar, Maclean and Beinart (2000, pp. 2, 6-8, 13-4).

${ }^{9}$ See also the quotes above, MOJ (2010), Ministerial Foreword p. 3, Executive Summary, para 4.3

${ }^{10}$ A Family Law Children Arbitration scheme was launched in 2016 (Resolution (2016)).

${ }^{11}$ See also Norgrove Report (2011a, paras 5.2, 5.58. 5.60).

${ }^{12}$ See Diduck and Kaganas (2012, p. 719) and the sources referred to there. See also Barlow et al 2014, p. 32.

${ }^{13}$ The assumptions underlying the criticisms of court and lawyers have been challenged (Eekelaar and Maclean 2013 pp. 4-7). Family courts are not entirely adversarial and it has been mainly solicitors, rather than mediators, who have provided the impetus for agreements (Eekelaar 2011, p. 314). Government has presented
} 
the alternatives as mediation or adjudication, ignoring the fact that many cases are resolved by solicitor negotiation (Eekelaar, Maclean and Beinhart 2000, pp. 7-8)

${ }^{14}$ See further, Kaganas (2010), (2011).

${ }^{15}$ See $R$ (Rights of Women) v Secretary of State for Justice [2016] EWCA Civ 91 para 41.

${ }^{16}$ See Public Law Project v Lord Chancellor [2015] EWCA Civ 1193 paras 5, 10.

${ }^{17}$ See also para 4.3 .

${ }^{18}$ See also Diduck (2011), (2014).

${ }^{19}$ See also Diduck (2016).

${ }^{20}$ See MOJ (2010), Executive Summary paras 1.3, 1.7, 1.8, 4.11; Cookson (2013). For the significance of cost on the government agenda, see also MOJ (2013a) and (2013b).

${ }^{21}$ See also MoJ, 2015, p. 3; MoJ, 2013b, Ministerial Foreword; Cobb, 2013, p. 4).

${ }^{22}$ See also Public Law Project v Lord Chancellor [2015] EWCA Civ 1193).

${ }^{23}$ I am indebted to Hilary Sommerlad for making this point.

${ }^{24}$ But most are required to attend a compulsory MIAM before being allowed to litigate (s. 10(1) Children and Families Act 2014; PD3A). It seems, however, that most couples manage to avoid even that: 'figures obtained by a Freedom of Information request to the Ministry of Justice show that in 2014/15 only one in 20

applications for applications for private law proceedings to a family court followed the new 'compulsory' route - fewer than 5,000 MIAMs from over 112,000 private law applications' (('95\% of Separating Couples Head Straight to Court', Family Law Week, 11 April 2016).

${ }^{25}$ According to Sommerlad, private law is now a commodity $(2015, \mathrm{p} .47)$.

${ }^{26}$ See Justice - Eighth Report. Impact of changes to civil legal aid under Part 1 of the Legal Aid, Sentencing and Punishment of Offenders Act 2012.

${ }^{27}$ See Equality Impact Assessment, Legal Aid Sentencing and Punishment of Offenders Bill, para. 15.

${ }^{28}$ See Judicial Executive Board, 2014, para 6. Numbers are still lower than pre-LASPO level but are now rising (MOJ Legal Aid Agency, 2015)

${ }^{29}$ See also Trinder (2015, p.238), Trinder et al. (2014, p. 116), Webley (2015, pp. 316-8).

${ }^{30}$ But see Lord Chief Justice of England and Wales (2016)

${ }^{31}$ See Grimwood (2016).

${ }^{32}$ See also para 2.123.

${ }^{33}$ See MOJ undated, para 2.124.

${ }^{34}$ See Treloar (2015, p.18).

${ }^{35}$ See MOJ undated, para 2.124, Trinder et al. (2014, p. 76).

${ }^{36}$ See p. 175. For example, a solicitor described a client who sought help after being pressured and intimidated.

${ }^{37}$ See Trinder et al. (2014, pp. 37, 47-50, 59).

${ }^{38}$ See also Trinder et al. (2014, pp. 73, 76).

${ }^{39}$ See also Coy et al. (2012, p. 46), ROW (2011), Trinder et al. (2014, pp. 13, 19).

${ }^{40}$ See MOJ (undated, para 2.128), Treloar (2015, pp. 17-18).

${ }^{41}$ See also MOJ (2011a, para 2.139).

${ }^{42}$ See also MOJ (2011a, para 2.135).

${ }^{43}$ See also MOJ (2011a, para 2.136).

${ }^{44}$ See also Welsh Women's Aid, Rights of Women, Women's Aid (2016)

${ }^{45} R$ (Rights of Women) $v$ Secretary of State for Justice [2016] EWCA Civ 91

${ }^{46}$ The number of private law cases has dropped since 2011-12 but has risen slightly compared with 2014-15

(CAFCASS Private law Demand. February 2016 Statistics from CAFCASS

https://www.cafcass.gov.uk/leaflets-resources/organisational-material/care-and-private-law-demandstatistics/private-law-demand-statistics.aspx (accessed 14 March 2016)

${ }^{47}$ See also Diduck (2016)

${ }^{48}$ In the context of commercial arbitration.

\section{References}

Atkin, B. (2015). The revised Family Court System in New Zealand: Secret justice and privatisation. In M. Maclean, J. Eekelaar \& B. Bastard (Eds.), Delivering Justice in the $21^{\text {st }}$ Century (pp. 39-50). Oxford: Hart Publishing.

Barlow, A., Hunter, R., Smithson, J., \& Ewing, J. (2014). Mapping paths to family justice. Briefing paper and report on key findings Exeter: University of Exeter. 
Barnett, A. (2015, October). Advice or coercion? Agreements for child arrangements in the post-LASPO landscape. Paper presented at the workshop, The post-LASPO landscape: Challenges for family law, Law \& Social Justice Programme, Leeds University. Bowcott. O (2017) Legal aid shakeup hands lifeline to domestic violence victims. The Guardian, 23 February https://www.theguardian.com/law/2017/feb/23/legal-aid-domesticviolence-law-courts (accessed 2 March 2017).

Beveridge, W. (1942) Social insurance and allied services. Cmd 6404. London: HMSO. Cobb, S. (2013). Legal aid reform: its impact on family law. JSW\&FL, 35:1, 3-19. doi: 10.1080/09649069.2013.774607

Cookson, G. (2013). Analysing the economic justification for the reforms to social welfare and family law legal aid. Journal of Social Welfare and Family Law, 35:1. 21-41. doi:10.1080/09649069.2013.774734

Coy, M, Perks, K., Scott, E. \& Tweedale, R. (2012) Picking up the pieces. Domestic violence and child contact. London: Rights of Women.

Cretney, S. (2005). Family law in the twentieth century. A history. Oxford: OUP. Department for Constitutional Affairs. (2005). A fairer deal for Legal Aid, Cm 6591. London: HMSO.

Department for Health and Social Security. (1974). Report of the Committee on One Parent Families Vol 1. London: HMSO.

Diduck, A. (2011). What is family law for? Current Legal Problems, 64, 287-314. doi:10.1093/clp/cur010

Diduck, A. (2014). Autonomy and vulnerability in family law: The missing link in J. Wallbank \& J. Herring (Eds) Vulnerabilities, care and family law (pp. 95-114). Oxford: Routledge.

Diduck, A. (2016). Autonomy and family justice. Child and Family Law Quarterly, 28, 133149.

Eekelaar, J., Maclean, M. \& Beinart, S. (2000). Family lawyers. The divorce work of solicitors. Oxford: Hart Publishing.

Eekelaar, J. (2011). "Not of the highest importance": Family justice under threat. Journal of Social Welfare and Family Law, 37, 311-317. Doi:10.1080/09649069.2011.632883

Eekelaar, J \& Maclean, M. (2013). Family justice. The work of family judges in uncertain times. Oxford: Hart Publishing.

Family Law Week. 95\% of separating couples head straight to court'. Family Law Week 
(11 April 2016).

Goodhart, A.L. (1945). Preface in R Egerton, Legal Aid (ix-xii). Abingdon: Routledge.

Grimwood, G. (2016). House of Commons Briefing Paper No 07113. Litigants in person:

The rise of the self-represented litigant in civil and family cases. London: House of

Commons Library.

Herring, J. (2010). Relational autonomy and family law. In J. Wallbank, S. Chaudhry \& J. Herring (Eds). Rights, gender and family law (pp. 257-275). Abingdon: Routledge.

House of Commons Debates. 15 December 1948. Vol 459. Legal Aid and Advice Bill.

House of Commons Justice Committee (2015). Eighth Report of Session 2014-15. Impact of changes to civil legal aid under Part 1 of the Legal Aid, Sentencing and Punishment of Offenders Act 2012. HC 311.

http://www.publications.parliament.uk/pa/cm201415/cmselect/cmjust/311/311.pdf (accessed 17 March 2016)

Hunt, J. \& Macleod, A. (2008). Outcomes of applications to court for contact orders after parental separation or divorce. London: Ministry of Justice.

Hunter. R. (2014). Exploring the LASPO gap. Family Law, 44, 660-663.

Hynes. S. (2012). Austerity justice. London: Legal Action Group.

Hynes. S. \& Robins, J. (2009). The justice gap. London: Legal Action Group.

Judicial Executive Board. (2014). Written evidence from the Judicial Executive Board (MSC 84), 13 May 2014: Key findings.

Kaganas. F. (2010). When it comes to contact disputes, what are family courts for? Current Legal Problems, 63. 235-271

Kaganas, F. (2011). Regulating emotion: Judging contact disputes. Child and Family Law Quarterly, 23, 63-93.

Lord Chief Justice of England and Wales. (2016). Reforming the courts' approach to McKenzie Friends. A consultation https://www.judiciary.gov.uk/wpcontent/uploads/2016/02/mf-consultation-paper-feb2016.pdf (accessed 21 March 2016).

MacGregor, S. (1999). Welfare, neo-liberalism and new paternalism: Three ways for social policy in late capitalist societies. Capital and Class, 23(1), 91-118.

doi: $\underline{10.1177 / 030981689906700104}$

McKibbin, R. (1998). Classes and cultures England 1918 - 1951. Oxford: OUP.

Ministry of Justice. (2010). Proposals for the reform of Legal Aid in England and Wales.

Consultation Paper CP 12/10. Cm 7967. London: TSO. 
Ministry of Justice. (2011a). Reform of legal aid in England and Wales. Equality impact assessment. London: TSO.

Ministry of Justice. (2011b). Reform of legal aid in England and Wales: The Government response. Cm 8072. London: TSO.

Ministry of Justice. (2013a). Transforming legal aid: delivering a more credible and efficient system. Consultation Paper CP14/2013. London: TSO.

Ministry of Justice. (2013b). Transforming legal aid: Next steps. London: TSO.

Ministry of Justice. (2015). Government response to Justice Committee's eighth report of session 2014-15: Impact of changes to civil legal aid under Part 1 of the Legal Aid, Sentencing and Punishment of Offenders Act 2012. Cm 9096. London: TSO.

Ministry of Justice and Legal Aid Agency. (2015). Legal aid statistics in England and Wales. April to June 2015. London: Ministry of Justice.

Ministry of Justice (undated) Equality impact assessment Reform of legal aid - equality impact assessment - Rightsnet (accessed 13 Oct 2015.).

https://www.google.co.uk/?gws_rd=ssl

Morgan, R. (1994). The introduction of civil legal aid in England and Wales 1914-1949.

Twentieth Century British History, 5, 38-76. doi:10.1093/tcbh/5.1.38

National Audit Office. (2014). Implementing reforms to civil legal aid. HC 784, Session 2014-15.

Norgrove, D. (2011a) Family Justice Review, Interim report. London: Ministry of Justice.

Norgrove, D. (2011b). Family Justice Review, Final report. London: Ministry of Justice.

Resolution. (2016). News release. Arbitration children scheme to be launched.

http://www.resolution.org.uk/news-list.asp?page_id=228\&page $=1 \& n \_i d=309$ (accessed 14 March 2016).

Rights of Women. (2011). The value of legal aid: case studies from individual women, professionals who respond to violence against women and legal professionals. London: ROW.

Rozenberg. J. (2016). Is English common law at risk of becoming out of date? BBC News (31 March 2016).

Rushcliffe, Lord. (1945). Report of the Committee on Legal Aid and Legal Advice in England and Wales. Cmd 6641. London: HMSO.

Smart. C. (1984). The ties that bind. Law, marriage and the reproduction of patriarchal relations. London: Routledge \& Kegan Paul. 
Sommerlad, H. (2015). Access to justice in hard times and the deconstruction of democratic citizenship. In M. Maclean, J. Eekelaar \& B. Bastard (Eds.), Delivering justice in the $21^{\text {st }}$ century (pp 243-264). Oxford: Hart Publishing.

Spencer, M. (2002). Public subsidies without strings--Labour and the lawyers at the birth of legal aid. International Journal of the Legal Profession, 9, 251-281.

Stone, L. (1990). Road to Divorce. England 1530-1987. Oxford: OUP.

Treloar, R. (2015). The neoliberal context of family law reform in British Columbia, Canada: Implications for access to (family) justice. In M. Maclean, J. Eekelaar \& B. Bastard (Eds.), Delivering justice in the $21^{\text {st }}$ century (pp. 15-38). Oxford: Hart Publishing.

Trinder, L. (2015). Taking responsibility? Legal aid reform and litigants in person in England. In M. Maclean, J. Eekelaar \& B. Bastard (Eds.), Delivering justice in the $21^{\text {st }}$ century (pp. 223-241). Oxford: Hart Publishing.

Trinder, L., Hunter, R., Hitchings, E., Miles, J., Moorhead, R., Smith, L., Sefton, M., Hinchly, V., Bader, K., and Pearce, J. (2014) Litigants in person in private family law cases. London: MOJ.

Webley, L. (2015). When is a family lawyer a lawyer? In M. Maclean, J. Eekelaar \& B. Bastard (Eds.), Delivering justice in the $21^{\text {st }}$ century (pp. 305-321). Oxford: Hart Publishing. Welsh Women's Aid, Rights of Women \& Women's Aid. (2016). Evidencing domestic violence: Nearly three years on. http://rightsofwomen.org.uk/wpcontent/uploads/2014/09/Evidencing-domestic-violence-V.pdf (accessed 21 March 2016) 